\title{
Regime Change and Public Protest in Poland: Comparing Past and Present
}

\begin{abstract}
Poland is currently facing a political regime change that erodes the country's democratic structures and undermines its judicial system. Resembling the Polish dissident movements that accompanied the transition from a socialistled to a democratic state in the late 1980 s, protest movements are recently emerging that aim to counter the illiberal tendencies of Poland's contemporary government. Civil society groups seem to accompany different types of regime change, either supporting the establishment of a democracy or fighting its disruption, making them a valuable indicator for the direction of political change. This chapter examines the relation between public protest and regime change based on a comparative case study of Poland. The findings indicate that the form of public protest gives insight into the type of political agitation. Civil society guiding a regime transition towards democracy acts from outside a country's political structures and targets the inside. A regime change that distances a country from a democratic set-up is marked by public protests that operate from within the state's structures, using the persistent democratic framework. Comparing the post-communist and today's stage of political upheaval in Poland thus reveals general patterns on the interaction between the public and the political sphere during a regime transformation process.
\end{abstract}

\section{Johanna Fleger ${ }^{1}$}

\footnotetext{
1 Johanna Fleger received a bachelor degree in European Studies at Maastricht University in 2017. She is currently working as research associate for the European Office of the Konrad Adenauer Foundation in Brussels. Contact: johanna.fleger@web.de
} 


\section{Introduction}

"We [Walesa and his compatriots] desire peace - and that is why we have never resorted to physical force. We crave for justice - and that is why we are so persistent in the struggle for our rights, we seek freedom of convictions - and that is why we have never attempted to enslave man's conscience"

\section{- Lech Walesa (Peace Prize Acceptance Speech, 1983)}

Merely a quarter century ago, Polish dissident movements attempted to shake off the communist system that dominated the government and penetrated into every part of society. Headed by Lech Walesa, a marine electrician, workers back then were fighting for independent labour unions. In 1980, Walesa could successfully negotiate the legalization of the trade union "Solidarity" with the authorities. Despite the workers' initial victory, Solidarity was banned one year later through the introduction of martial law by the Polish government that was intended to suppress political opposition. Nevertheless, the workers' movement had profoundly undermined the foundations of the communist state system and had left a lasting imprint that reflected the potential strength of societal demands. Only seven years later, Walesa was invited to join Round Table talks with the communist authorities and a new government was elected. The former shipyard electrician became President of Poland in 1990, standing symbolically for the success of popular movements that peacefully combated the communist regime (Ackermann \& Duvall, 2000, p. 2). Walesa's engagement for the freedom of organization and his campaign against communist predominance has been rewarded with the Peace Prize in 1983. The introductory quote is an excerpt from his acceptance speech, underlining the Polish workers' tireless commitment for justice, rights and freedom of conviction (The Noble Foundation, 1983).

However, the deep appreciation of these democratic values that was driving the Polish dissident movements seems to dwindle away in today's society. Justice, rights and freedoms got increasingly disconnected from Polish politics since the Law and Justice Party (PiS) won the 2015 presidency elections, securing a parliamentary majority. Under Jaroslaw Kaczynski, the nationalist PiS party currently attempts to take control over the High Court, the public media and the bureaucracy, leaving oppositional forces little room to manoeuver (Fomina \& Kucharczyk, 2016, p. 58). This emerging form of authoritarian populism causes European politicians to frequently voice concerns on the state of democracy in Poland: "... what alarms most members of this House and what a democrat never does, is to use a parliamentary majority to dismantle a country's system of checks and balances" (Verhofstadt, 2016). In this context, a connection is often established between current political upheavals and former anti-communist resistance movements such as Solidarity: "Knowing the Polish people, the people who gave rise to 'Solidarnosc', who resisted repression and who fought for freedom, for democracy, for the rule of law, I am convinced they will never accept to give up democracy again" (Verhofstadt, 2016). Democracy is occurring as a central element that connects the post-communist political transformation towards democracy and today's anti-democratic tendencies. Both stages in Polish 
politics resemble each other as they are representing political turning points that are accompanied by governmental and societal changes. Based on this comparison, this chapter characterizes past and contemporary developments in Poland's political landscape as a form of regime change, one from an authoritarian to a democratic system and the other from a democratic towards an increasingly autocratic political set-up.

Although both periods are equally marked by an agitation of the political system, civil society responds differently each time to the erosion of state structures. It is striking that current political developments such as the increasing entrenchment of autocratic elements within the Polish government are accompanied by a different form of public protests than the political transformation in the communist era. As social protest is assumed to have "profound effects on the quality of democracy" it is reasonable to assume that public protest movements are closely linked to the process of regime change that is endangering the continued existence of an already established political system (Alemann, 2015, p. 21).

Aiming to reveal the concrete mechanisms that connect public protest and regime change, this chapter examines the relation between both concepts. In particular, it examines why the Polish post-communist regime change towards democracy was accompanied by a different form of public protest than today's anti-democratic political transformation. Investigating the Polish case helps to answer the overarching research question of how the form of public protest is related to the type of regime change and whether public protest can be seen as an indicator for the type of political transformation, either towards a democratic system or away from it. The chapter argues that public protest and regime change are closely interlinked: The form of public protest gives insight into the type of regime change and the direction of transformation, rendering protest movements an important indicator for political developments. The analysis of the Polish case and the specific link between politics and society thus contributes to make the Europe-wide phenomenon of emerging antidemocratic politics more graspable. The chapter's findings can for instance be transferred to other European countries such as Hungary where, comparable to the Polish case, various grassroots movements, such as the youth party "Momentum" attempt to counter Prime Minister Viktor Orbán's gradual establishment of an "illiberal democracy" (Friedman, 2016; Varga, 2017).

\section{Explaining Public Protest and Regime Change}

As the chapter explores the nexus between public protest and the form of regime change in Poland, literature on both concepts and their classification in academic work builds a valuable basis for the comparative analysis. Most scholars have only been taking into account public protest as a proper form of political participation since the 1970 s. Prior to this, public protest was mainly absent in academic literature and was reduced to an irrational and disruptive form of political activity (Quaranta, 2013, p. 459). In 1979, a study by Barnes and Kaase introduced a more nuanced view on political activity by introducing a distinction between conventional and unconventional forms of action. The former is referring to all acts of public interest expression that take place within the constitutional process and are guided by political institutions. The latter, 
occasionally labelled "political protest", includes non-institutionalized and direct political action (p. 459). This distinction diversified theoretical perspectives on collective action and academic research began to increasingly concentrate on the object of political participation. While conventional action aims to influence public institutions and the political arena, unconventional action can be targeted at the public and the private sector (p.460). Building on the findings by Barnes and Kaase, other scholars recognized public protest as a rational and participatory form of political action that goes beyond the irrational expression of public sentiments (Van Aelst \& Walgrave, 2001, p. 462). The shift of perception in academic literature shows that collective action has been normalized and transformed into a common tool of public expression, rendering the traditional distinction between conventional and unconventional forms of political participation superfluous (Norris, 2002, p. 190). Generally acknowledging public protest as a form of political expression, Norris (2002) contributed a framework that allows to analyse changes in the form of public protest. She refers to agencies, repertoires and targets as three basic indicators that can be used to detect transformations in the manifestation of protest. Norris' categorisation structures the comparative analysis, helping to detect similarities and differences between the two stages of Polish politics.

Engaging with the academic literature reveals that the concept of public protest is frequently analysed in an isolated manner, concentrating on aspects such as the societal origins of collective action, the ways that citizens choose to politically participate and different methods to measure the extent of public protest. Moreover, public protest is often regarded within the set-up of a democratic state: "Political participation and political protest are building blocks of democratic regimes" (Quaranta, 2015, p. 1). Existing approaches neglect the role of public protest in other types of political regimes or within a stage of regime transformation. In order to address these flaws and to reveal how political and societal spheres interact during a period of political upheaval, the chapter introduces regime change as a second concept that can be analysed in connection to collective action.

Academics commonly deal with typologies of regimes, the particular consequences of a regime change, and citizens' reactions to political transformation processes. Tilly and Tarrow (2015), for instance, single out two factors that account for the differences between political regimes. First, governmental capacity, including the extent to which the government's action has an influence on the nature and distribution of population, activity and resources. Second, democracy, referring to the existence of equal political rights and the degree of direct influence that people possess as subjects to a given government (p. 57). Aleman (2015) distinguishes between two regime dimensions depending on the degree of contestation and inclusiveness. Contestation relates to the existence of parties and politicians from which citizens can chose the one that is most aligned with their preferences, while inclusiveness describes the ability of political participation in the selection of leaders and policies by as many people as possible (p. 8). Extending Aleman's emphasis on democratic regimes, Utfelder (2005) confines his study to authoritarian regimes and the effect that collective action has on them. He offers a new categorization of political systems, differentiating between personalistic, single-party and military regimes and elaborates on their vulnerability towards collective action in society. Rose and Mishler (1994) are also thinking along these lines by focusing on the connection between regime 
changes and the accompanying reactions in society. As they regard public protest as a response to a specific form of political transformation, the scholars are already hinting at the existing link between both concepts, implying that public protest is an indicator for the type of regime change.

As the chapter is dealing with stages of political transformation, Merkel's and Maoz's contributions to regime change are of particular relevance. Merkel (1999) goes beyond static definitions by presenting a fourfold distinction that includes the concepts of regime conversion, change, transformation and transition (p. 74). Maoz (1996), in contrast to Merkel's rather nuanced differentiation, is taking a more simplified approach based on the demarcation between regime change and transformation. The former involves a new distribution of capabilities among the political players, while the set-up of the core institutions and the system of political rules remains intact (p. 179). The latter leads to changes at all levels of the political system, affecting the distribution of power and responsibilities as well as the rules of the game that define the relationship between the public and the institutions (p. 180).

The academic literature presented helps to gain a general comprehension of the two main concepts that the chapter deals with. Understanding the phenomena of public protest and regime change is a necessary precondition for subsequently linking these two variables in the context of Polish politics. However, the literature review reveals gaps in scholarly work. First, most approaches focus on either public protest or regime change, failing to address the potential nexus between both concepts. Second, most authors limit their analysis of political transitions to the shift from an authoritarian system to a democratic one, thus to the process of democratization. Consequently, the literature overlooks the reversed development of a political system that transforms from a democracy into an authoritarian regime. Third, there is a lack of comparative approaches that contrast two political stages within one country. Despite general allusions to the resemblance between communist dissident movements and today's expressions of public discontent, the literature is not further exploring this connection. This chapter addresses these flaws and contributes to academic research by comparing two reversely proceeding stages of regime change within one country and by linking these findings to the accompanying public protest movements in society.

\section{Establishing a Link between Public Protest and Regime Change}

By comparing public protest during the Polish transition from authoritarianism to democracy in the post-communist era with the public protest movements occurring in response to recent political transformations, this study explores existing parallels and differences in public reactions between those two periods. Based on the assumption that public protest counts as an indicator for the type of regime change, the analysis aims to reveal the mechanisms that link public protest and political transformation processes. In the following part, the chapter outlines the further structure of the analysis, while simultaneously explaining the core concepts that the study is based upon.

First, the chapter focuses on regime change and analyses whether the post-communist and today's period in Poland's development can actually be 
classified as such. Generally, a regime determines who has access to political power and how political power is used (Lawson, 1993, pp. 185-87). Regime change can be described as a state of transformation that is located between reform and revolution and that can "establish democratic regimes instead of authoritarian ones or vice versa" (Huber et al., 2015, p. 20). Despite the potential distinction between political regime change and transformation that is used by scholars such as Maoz (1996) and Merkel (1999), the chapter employs both terms interchangeably in order to facilitate the analysis. According to Maoz, a regime change generally involves a fundamental shift in the distribution of power among the political institutions and an alteration of the rules that govern the relation between political institutions and citizens (p. 180). These characteristics serve as a reference point for the analysis.

Second, the chapter deals with public protest. The term is commonly used to describe a direct form of political action that takes places in the absence of mediating, institutional actors and aims at influencing either governmental institutions or the private sector (Quaranta, 2015, p. 24). In order to study and compare post-communist and present-day protest movements, the chapter employs Norris' (2002) three features including agencies, repertoires and targets. Agencies refer to the organizational structures through which people mobilize for political expression. Repertories stand for the way citizens choose to politically express themselves and the various modes of participation in society ( $\mathrm{p} .3$ ). The third element, targets, comprises the actors that people intend to influence through collective action (p. 5). Norris claims that these elements have evolved and diversified during the post-war era, making them valuable indicators that capture changes in the form and extent of public protest (p. 3). The chapter opts to investigate two specific public protest groups in Poland in order to allow for a structured comparison: First, the Solidarity movement, whose origins can be traced back to the foundation of the Worker Defense Committee (KOR) in 1976 and that represents Polish dissident movements during communist times. Second, the Committee for the Defense of Democracy (KOD) that counteracts the establishment of an authoritarian government in present-day Poland. Solidarity thus represents a civil society movement that accompanied the transition from authoritarianism to democracy. Its contemporary counterpart, KOD, addresses currently unfolding developments that are moving Poland away from democratic politics towards authoritarian state structures.

Finally, the insights on public protest and regime change in both stages of Polish politics are combined. Merging those two concepts helps to answer the overall research question, whether the form and extent of public protest is an indicator for the type of regime change, reflecting the direction of political transformation. Methodologically, the chapter follows a comparative historical analysis that allows to "engage in systematic and contextualized comparisons of similar and contrasting cases" (Mahoney \& Rueschemeyer, 2003, p. 13). Secondary and primary sources such as academic articles, studies, manifestos and speeches serve as evidence to support the chapter's main arguments. By adopting a historical perspective in combination with the analysis of contemporary developments, overarching patterns can be discovered that can be transferred to other examples apart from the Polish case, adding to the study's academic relevance. In this way, it raises awareness for the continuing importance of past events that shaped a country's history and that can be helpful to grasp today's political and societal dynamics. 


\section{Regime Change - Comparing Past and Present}

"To understand the nature and dynamics of political democracy in today's Poland, it is necessary to take a closer look at the developments that took place in the early days of the systemic transformation" (Puchalska, 2005, p. 816). As the quote implies, seemingly distinct and temporally separated stages of Polish politics can be mutually influential, rendering an analysis of the past valuable to comprehend contemporary developments. The chapter follow's Puchalska's line of reasoning by establishing a link between Poland's post-communist and the present-day transformation phase. Assuming that both political stages can be classified as a form of regime change, they should be marked by a change in the distribution of power among the main political actors and by a revision of the rules that govern the relation between institutions and citizens (MaOz, 1996).

The analysis of the communist regime change is temporally confined to the late 1980s and early 1990s when the Central and Eastern European countries entered a process of political transition (Ekiert, 1991, p. 287). In Poland, the first free parliamentary elections were held in 1991, reflecting a shift towards an increasingly democratic set-up and the beginning of the postcommunist period (Millard, 1991, p. 387). This development was accompanied by a change in the overall power structures among the political institutions in Poland, in line with Maoz's first feature of regime change. The groundwork for the consolidation of democratic elements during the Polish transition from socialism was laid by the Round Table Agreement in 1989, concluded between the communist leadership and the representatives of the Solidarity opposition: "...the negotiations played a crucial role in launching the ongoing process of change in Eastern Europe" (Osiatynski, 1996, p. 21). Amongst others, the agreement included the introduction of competitive, parliamentary elections, the creation of a presidency and the re-establishment of the Senate (Glenn, 2001, pp. 92-96). These mechanisms and the practice of solving governmental matters through negotiations became "durable legacies" that moved the Polish government further towards democracy (Osiatynski, 1996, p. 21). The political reform process culminated in the implementation of a new constitution in 1997 that completed the process of democratic transition and "defined the power relationship between the government and the people for years to come" (Puchalska, 2005, p. 820).

Evaluating academic studies on the post-communist phase of transformation reveals that most scholars are interpreting the years between 1989 and 1991 as the beginning of democratization in Poland. This is reflected in the frequent use of the term "transition", pointing to a regime change towards a democratic system of government (Suchoka, 2015, p. 21; Bunce \& Wolchik, 2010, p. 36; Linz, 1996, p. 269). Hence, the political developments in the Polish post-communist era are in line with Maoz's definition of regime change and can be classified as such. The process of democratization involved a profound alteration in the distribution of power and the set-up of new political structures that are governing the relationship between the institutions and the citizens. "Poland in 1988-89 was an authoritarian regime led by party-soldiers - and was the first of East Europe's transitions" (Linz \& Stepan, 1996, p. 255). 
Moreover, as the section's initial quote suggests, it is insightful to establish a link between past transition processes and present developments in Polish politics. A comparative approach that considers two distinct stages of political agitation helps to assess contemporary politics in Poland in relation to a historical benchmark. According to the Freedom House "Nations in Transit Report", Poland's overall democracy score in 2016 deteriorated from 2.32 to $2.57^{2}$, mirroring a weakened democratic performance in the civil society sector, the media and within the judicial framework (Freedom House, 2017, p. 3). The report is tracing back the imminent anti-democratic tendencies to the PiS-led government that is currently steering the Polish state. The ruling Party transforms public media into a governmental instrument, restrains the Constitutional Tribunal in its independent oversight function and passes unconstitutional amendments (pp. 2-3). In response to these developments, the European Commission launched an official investigation to uncover possible breaches of EU standards in January 2016 (Fomina, 2016, p. 64). Complementarily, a set of recommendations to the Polish government has been issued twice, in July and December 2016, in order to address the ongoing weakening of the rule of law and the increasing instrumentalization of the judicial system (European Commission, 2010). Especially as the rule of law is a "primary requirement for democratic consolidation", the increasing exploitation of the judicial branch to pursue political goals demonstrates that democratic structures are eroding (Morlino, 2006, p. 10). As a reaction, numerous civil society groups appeal to the European institutions to take firm action against the current rule of law violations in Poland. Their reservations about the state of politics are expressed in an Open Letter to the College of Commissioners, indicating that the PiS-government alters democratic power structures and the way society is governed: "...the changes impacting the Constitutional Tribunal are part of a wider sequence of reforms which undermine checks and balances and restrict human rights in Poland" (Open Letter, 2017).

Consequently, current developments in Polish politics are following anti-democratic tendencies and have "hallowed out Poland's liberal-democratic foundations" (Buras, 2017). Regarded in relation to the political transformations in the late 1980s, Poland undergoes a second regime change. The shift of power structures, the weakening of the rule of law and the redistribution of responsibilities amongst political institutions coincide with Maoz's features of political regime transformation that include a "fundamental change of the political rules of the game [and] a redefinition of the distribution of authorities over political institutions" (1996, p. 179). However, in comparison to the post-communist transition to democracy, contemporary developments reverse the former democratization process as they evolve from a democratic towards an autocratic set-up. As Maoz's definition includes political transformations in either direction, this chapter argues that both stages of Polish politics can be characterized as regime change. A basis for comparison between past and present developments is thus established, allowing to link the general concept of regime change with the chapter's second concept of public protest.

\footnotetext{
${ }^{2}$ Ratings are based on a scale of 1 , highest level of democratic progress, to 7, lowest level of democratic progress
} 


\section{Public Protest - an Indicator of Regime Change?}

The general interplay between collective action in society and political transformation has been investigated by various scholars (Tarrow, 1988; O'Donnell \& Schmitter, 1986). However, their research has often been confined to a link between public protest and the process of democratization, frequently concluding that collective action is "neither a necessary nor a sufficient condition for democratization, [but] may be a decisive factor in a significant subset of regime transformations" (Utfelder, 2005, p. 313). Even though the existence of a general nexus between public protest movements and political change is thus not being neglected, there is a need to extend the scholars' onedirectional approaches that overlook other forms of regime transformation. To this end, the chapter explores the connection between protest movements and political transformations in either direction, including the establishment of democratic structures as well as their abandonment. The following analysis offers insights into the way different forms of public protest are interacting with various types of political change, specifically focusing on Solidarity and the Committee for the Defense of Democracy (KOD). The performances of both movements are compared and assessed by investigating their respective agencies, repertoires and targets (Norris, 2006).

\subsection{Solidarity and the Process of Democratization}

Studying the Polish transition phase towards democracy at the end of the 1980 s reveals that "the political behavior of the citizens under communism underwent change in tandem with regime performance", underlining the chapter's general assumption of an interplay between public protest and political transformation processes (Castle \& Taras, 2002, p. 52). This pattern is reflected in the way Solidarity exercised opposition to socialist state politics. By making use of specific agencies, repertoires and target groups, the dissident movement was able to influence the Polish transition from an authoritarian to a democratic regime, implying that societal action is revealing on the direction and type of political transformation.

\subsubsection{Solidarity's agencies}

Solidarity's agencies or mobilizing structures were shaped by the principle of self-organization and the idea of a civil society based on the right of every group to form an independent organization that can articulate its own interests (Kennedy, 1991, p. 1). These guiding principles were reflected in the movement's internal composition that included workers, white-collar employees, intellectuals and entrepreneurs (Castle \& Taras, 2002, p. 56). Solidarity's pluralistic set-up enabled the movement to mobilize a broad spectrum of society and to embrace various political tendencies, confronting the authoritarian regime with the pursuit of democratic principles within a socialist state system (Kennedy, 1991, p. 2). The dissident movement's unique internal structure offered society a platform to mobilize horizontally and to advocate their demands. Some scholars even argue that Solidarity's strong 
stance in civil society led to the creation of a dual power structure between the Party and the Trade Union (Linz \& Stepan, 1996, pp. 262-63).

Providing an overall framework for mobilization in the form of a trade union, the movement successfully combined various self-governing groups such as workers and intellectuals: "Long-standing worker activism triggered the birth of the Solidarity movement, but it was undergirded by a consensus crystallizing across all groups in society about the terminal crisis in communism" (Castle \& Taras, 2002, p. 55). Even though Solidarity was based on workers' activism as the main driver for change, its internal set-up was characterized by openness towards other societal groups, contributing to the movement's ability to mobilize broad sections of society and enabling collective activism to evolve beyond mere riots. Solidarity's organizational structure can be traced back to its origins rooted in the KOR movement that was shaped by the collaboration between intelligentsia and workers. The connection between those two groups persisted when Solidarity became an independent trade union in 1980 and the intellectuals continued to structure the workers' strikes and to support negotiations with the authorities (Laba, 1991, p. 4). Solidarity thus enabled Polish people to mobilize within the framework of a labor movement, offering an inclusive platform for political expression that embraced not only workers, but various societal groups.

\subsubsection{Solidarity's Repertoires of Action}

Solidarity's origin as a trade union is still reflected in the movement's repertoires of action. Its activities are mainly associated with workers' strikes and protests that scholars formerly categorized as unconventional forms of activism (Barnes \& Kaase, 1979). The more democratization progressed, the more political became these unconventional forms of collective action in order to secure continued access to the socialist state government. A central element shaping Solidarity's activities was the principle of non-violence and the notion of a peaceful transition towards democracy as a former member of the Citizens' Committee confirms: "Its [Solidarity's] mode of operation was indeed the rejection of violence..." (Hall, 1999, p. 33). The Trade Union's actions were characterized by a tandem interplay with the strategies followed by the Polish government, hinting at Solidarity's general willingness to negotiate and compromise beyond the exercise of strikes and protests. Prior to the Round Table talks in 1989 that marked the beginning of a democratic transition through a negotiated "mode of exit", Solidarity had to frequently adapt its repertoires to the prevailing tactics of the communist-led government (Millard, 1999 , p. 9). Initially, Solidarity followed KOR's ideology by limiting itself to antipolitical actions and focusing on the emancipation of civil society within the state socialist environment (Ost, 1990, p. 75). From the 1970s onwards, however, protests frequently occurred amongst Polish workers. Riots in Gdańsk (1970) and in Radom (1976) were triggered by imminent economic reform and accompanying price increases. Strikes crystallized as the primary mode of political expression and created the need for a permanent organization to represent their long-term interests (Paczkowski \& Byrne, 2007, p. 3). Polish workers thus "played the paramount role of agents of change in People's Poland" (Castle \& Taras, 2002, p. 55). Their unconventional expression of disapproval with the communist dominated civil society eventually led to the birth of the Solidarity movement in 1980. As the Trade Union became a 
representative of large parts of the Polish civil society, the communist party's reach was reduced to controlling the army and the security services.

In order to counter the ongoing weakening of the socialist state, General Jaruzelski introduced martial law in December 1981 and established a government dominated by the military (Linz \& Stepan, 1996, p. 263). Workers attempted to respond by initiating new strikes, but as most of the Solidarity leaders were imprisoned they were left without guidance. The movement's inability to continuously mobilize civil society under martial law shows that, from the outset, Solidarity's repertoires were geared towards open negotiations with political authorities rather than for illegal underground activities (Ost, 1990 , p. 151). Martial law did not lead to a political settlement between political actors and civil society. Instead, it deepened the divide between the "we" of society and the "them" of the Party. Even though Solidarity was officially banned, the public still strongly identified with the movement as a platform of mobilization. Eventually, the government's repressive tactics and Poland's deteriorating economy led to a renewed outbreak of collective action in 1988, marking the beginning of a new form of interplay between public and government actors (Millard, 1992, p. 8). The Party realized that only entering into talks with Solidarity could end the workers' revolts, leading the Trade Union to abandon its anti-political approach and broaden its repertoire of action. Once the Round Table talks commenced in August 1988, Lech Walesa called on the workers to end the strikes, indicating that the Trade Union and the government mutually adjusted their actions (Bloom, 2013, p. 372). The talks resulted in the re-legalization of Solidarity and the movement finally won a decisive victory in Eastern Europe's first free elections in forty years.

Poland's transition process towards democracy was thus characterized by a continuous interplay between the Party and civil society. Solidarity's repertoire of action ranged from unconventional protest strikes to formal negotiations, depending on the government's response and willingness to employ repressive methods. Generally, the movement acted according to a corporatist approach, striving for an arrangement that would link the organized interests of civil society with the decisional structures of the socialist state (Ost, 1990, p. 114). The focus on civil society and the self-governance of interest groups was central to all forms of collective action, as Bronislaw Geremek, one of Solidarity's leading strategists and Walesa's most influential advisor, confirms: "... all of our strength at the Round Table rested precisely on the fact that we spoke the language of society and acted as its representatives" (Geremek, 1989).

\subsubsection{Solidarity's Target Groups}

Solidarity's target groups, the third feature of Norris' (2006) framework, can be derived from the preceding analysis of the movement's repertoires of action. By following a dual strategy of combining protest opposition and formally led negotiations, Solidarity aimed at influencing the socialist party state and simultaneously at building up a form of partnership between civil society and state that would benefit both sides: "...determination [was] necessary to pressure the government to accept Solidarity as a partner; discipline, moderation and willingness to retreat were needed to convince the government 
that Solidarity could be a reliable partner" (Ost, 1990, p. 125). Due to the Party's dominance in all parts of society and politics, a form of collaboration could not be circumvented as the communist party represented the only point of access to the Polish state. Solidarity's actions were thus clearly stateoriented, balancing between the role of an oppositional movement and a formal institution.

Hence, Solidarity's actions were primarily targeted at the state, reflecting the prevailing line of conflict between the civil society and the regime's authoritarian system at the time. Marked by the constant interplay between "us" and "them", the Polish regime transformation is sometimes referred to as a "pacted transition" towards democracy that involved an agreement between the regime and the opposition moderates (Linz, 1996, p. 61).

\subsection{KOD and the Present-Day Regime Transformation}

Having engaged with the collective action pursued by Solidarity, the chapter refers to a second case in order to assess whether different types of public protest can be put in direct relation to different kinds of regime change. As aforementioned, Poland is currently undergoing a second political transformation that moves the country away from democracy, altering existing power structures and the state's institutional set-up. However, present-day public protest that counters anti-democratic tendencies seems to be expressed differently, compared to civil society activism that accompanied the postcommunist era. Equally analyzing KOD's agencies, repertoires and targets helps to evaluate whether and in what way the current regime change is influenced by collective action directed against the practices of the ruling PiS-government.

The idea of creating a committee in defense of democracy originally stemmed from Krzysztof Łoziński, a Polish publicist, writer and anti-communist opposition activist. Alarmed by PiS's announcement that the Polish government is in need of radical change in the functioning of democracy and a new constitution, Łoziński appealed to the Polish society in his column to form a civic protest movement in order to defend democracy in their country (Łoziński, 2015). Following this call, the hitherto unknown IT technician Mateusz Kijowski launched a Facebook group to promote Łoziński's idea, offering a platform for many to express their concerns regarding the PiS government's political course (Cienski \& Harper, 2016). Only three days after its creation in November 2015, the Facebook initiative counted 30.000 members and the "Komitet Obrony Demokracji" left the virtual space to become an actual public protest movement with Kijowski as the campaign's most prominent proponent (Schlieben \& Dülffer, 2016).

\subsubsection{KOD's Agencies}

The initiative's apparent allusions to the KOR opposition movement acting under Poland's communist regime, point towards KOD's agencies and organizational structures. Frequent references to dissident activities in socialist times are part of the movement's set-up, used to mobilize civil society. By 
adopting KOR's way of framing collective action and evidently referring to the dissident movement's name, KOD transmits the impression that society has to equally mobilize against the anti-democratic actions of the current government. Similar to the intelligentsia's approach to opposition in the 1970s, the presentday Committee emphasizes its intention to establish a counter-public and to change government policies by exerting normative pressure. As a consequence, an "us" versus "them" dichotomy is created that resembles the one perceived by dissident groups under the communist regime and supports the image of the government being an authoritarian institution (Karolewski, 2016, pp. 261$62)$.

Even though KOD closely follows anti-communist dissident strategies, drawing on their legacies' symbolic strength, today's movement mobilizes civil society in a different way, drawing on a combination of social and political elements. While Solidarity as a trade union had to operate outside political structures, advocating both workers' and overall civil rights, KOD is still working within a formally democratic system that enables the movement to exert influence through political channels. The parliamentary opposition, for instance, uses the Committee as a platform to voice its concerns. In that way, the opposition increases pressure on the government, rendering KOD a politicized social movement and political interests its main driving force (NowickaFranczak, 2016). Another element that characterizes KOD's agencies and differentiates the movement from Solidarity is the international context that the present-day civil society operates within. Despite KOD's internal similarities to anti-communist dissident groups, today's movement develops in a different environment. In the post-communist era Poland was about to become a democratic country, member of the EU and part of international alliances such as NATO (Cienski \& Harper, 2016). KOD already uses this common, European identity as a uniting element and thereby positions itself in opposition to the PiS government that views the EU as a source of "illegitimate political pressure" (Karolewski, 2016, p. 264).

Evaluating KOD's agencies and comparing them with Solidarity's strategies reveals striking similarities between both movements. KOD mobilizes civil society by deliberately employing anti-communist symbolism and alluding to the dissidents' legacy that needs to be defended against the current government's authoritarian tendencies. However, while Solidarity's role was confined to that of a social movement operating within civil society, the Committee's structures blur the line between civil and political society. KOD's set-up is based on a more visible link to the Polish government, leading to frequent criticism that the Committee is instrumentalized for political purposes (Skóra, 2016).

\subsubsection{KOD's Repertoires of Action}

KOD's repertoires of action show once again that the movement was born in a different era than Solidarity: An era that allows for new and "unconventional" forms of public protest, in contrast to the anti-communist opposition activities (Barnes and Kaase, 1979). KOD's emergence as a social media initiative allowed the movement to provide access for various national and international adherents. As stressed in its manifesto, KOD's supporters are committed to "express [their] mind not only at home or on the Internet, but also in the streets 
and squares of our cities, towns and villages, gathering there when there is a need to express our opinions and demands" (KOD, 2015). The Committee's activities include sit-ins, petitions, open-letters and demonstrations. These methods are comparatively less confrontational than Solidarity's strike actions with workers blocking whole factories and workplaces. In December 2015, the first large demonstration took place in Warsaw where 50.000 Poles protested against the PiS government and expressed their attachment to the European Union (Karolewski, 2016, p. 259). Since then, civil society frequently gathers in public to express its opposition to the current political course (Trappmann, 2016 , p. 75). Reflecting the movement's international reach and mobilizing strength, Polish KOD campaigns were copied in cities like Berlin, Brussels and London.

Overall, the Committee's repertoires are in line with Norris' description of contemporary direct action that embraces both social and political elements, rendering a strict demarcation superfluous (2002, p.192). On the one hand, KOD refers to liberal, democratic values and operates within the political sphere. On the other hand, the Committee embraces a form of "lifestyle" politics that underlines the movement's social component and appeals to the people's common, European identity. In comparison to Solidarity's actions, KOD's repertoires are less confrontational than the activities of the anticommunist dissidents. As today's movement operates within democratic structures that allow for the expression of public opinion, it is able to circumvent radical and illegal forms of collective action.

\subsubsection{KOD's Target Groups}

Taking into account KOD's agencies and repertoires, Norris' (2006) first two features, gives insight into the movement's targets of participation. Due to the Committee's international reach, its audience is not confined to a specific geographical area. Social media platforms allow KOD to mobilize an international community in addition to the domestic civil society. Even though the Committee's demands are primarily addressed to the Polish government, directly responding to the on-going political transformations and the perceived loss of political rights, KOD's targets are stretched out beyond national borders. As the movement deliberately integrates the EU as a political actor, KOD is able to put further external pressure on national politicians. As Roger Casale, Founder and CEO of civil society organization "New Europeans", emphasized when he awarded the European Citizens' Price 2016 to KOD: "The work of Mateusz Kijowski and KOD is not just for the people of Poland, it is done on behalf of the citizens of Europe" (2016). Evidently, the Committee for the Defense of Democracy is operating within a more integrated, open and democratic system than Solidarity under the socialist, authoritarian regime. This allows KOD to address a wider range of target groups and to operate on an international scale. While Solidarity's exercise of political opposition was limited to the national, authoritarian framework, KOD can project its demands onto an international platform, allowing it to address the PiS government with greater vigor (Karolewski, 2016, p. 263). 


\section{Comparing Solidarity and KOD in the Context of Regime Change}

The comparative analysis of both movements' agencies, repertoires and targets reveals similarities as well as differences between Solidarity's and KOD's actions. The existing similarities are indicating that KOD continues to act in line with Solidarity's legacy. By adopting the post-communist labor movement's focus on the creation of a strong and politically conscious civil society and by referring back to the dissidents' struggle for democracy, KOD mobilizes people through reviving Solidarity's spirit. However, both movements operate within diverging state structures, addressing two different types of political upheaval. As already identified, Solidarity accompanied a transition from an authoritarian towards a democratic system, while KOD intends to counter the currently emerging tendencies towards authoritarianism. Despite their similarities, the way in which both movements exercise public opposition is differing as they adapt their tactics to the respective political environment. Consequently, both social movements can be counted as indicators of a different kind of political transformation process and have adjusted their activities according to the direction of the regime change (Trappmann, 2016, p. 66).

For instance, Solidarity's repertoires of action matched the initially prevailing, authoritarian environment as the movement exerted pressure mainly through workers' strikes. Due to the "pacted" nature of the transition process, Solidarity changed its tactics in accordance with the progressing democratization and adopted political strategies that signaled a certain openness towards the Polish government, eventually leading to a negotiated solution between the socialist Party and its opposition. The Trade Union benefitted from its ability to employ conventional as well as unconventional methods of public expression, allowing it to operate as a social movement as well as an institution, dependent on the prevailing political mood. Due to the movement's mobilizing strength, the Party was forced to secure Solidarity's willingness to cooperate, eventually leading to a corporatist arrangement between state and society.

The comparative analysis has further shown that KOD's agencies, repertoires and targets are partly diverging from Solidarity's methods. Today's movement thus counters a form of regime change that evolves into the reverse direction, gradually installing authoritarian elements within Poland's formally democratic state structures. Even though KOD to some extent represents a continuum of Solidarity's legacies and draws its mobilizing strength from these historical ties, the Committee operates on a wider, international scale. Unlike Solidarity, KOD can rely on a persisting democratic framework that enables it to embrace open and less confrontational strategies. This environment allows the Committee to merge political and social forces, offering a platform for oppositional parties and simultaneously acting as a citizens' movement. The access to an international audience through social media further strengthens KOD's mobilizing ability and its position vis-à-vis the current PiS-government.

Considering these particular findings and detaching them from the Polish case, reveals two general mechanisms that characterize the interplay between the form of public protest and the direction of political transformation. First, a state transformation towards democracy is accompanied by public protests that operate from outside the political system, but target internal state 
structures. As Solidarity's case has shown, autocratic state structures prevent civil society movements from exerting influence through regular, political channels. Instead, citizens have to rely on rather unconventional forms of public expression such as strikes in order to gain access to political dialogue in the first place. These civil society movements have to find a way to demonstrate their strength within the autocratic and repressive state structures that are created to prevent any form of opposition. Second, a political transformation that distances a state from its originally democratic set-up is by implication accompanied by public protests that operate from within the still existing political structures, but that target the outside. As the analysis of KOD's activities has exemplarily shown, these movements can fall back on partly intact democratic structures, allowing them to circumvent unconventional forms of political expression. Operating from within the state system, civil groups such as KOD can rather focus on communicating their demands to external actors, such as the EU, and to gain attention from the international community.

\section{Conclusion}

In 1998, Solidarity's most prominent labor activist Lech Walesa opened his speech in front of the American Congress with the powerful slogan "We the people" (Hill, 2014, p. 43). The very same slogan guided a march under the lead of the Committee for the Defense of Democracy in February 2016 in Warsaw, showing that nearly 20 years later these words continue to capture the prevailing mood in the Polish society (Nowicka-Franczak, 2016). The return to anti-communist symbolism in response to contemporary political transformations indicates that the dissidents' legacies are still playing a powerful role for Poland's civil society, leading people to mobilize and jointly express public opposition against the current anti-democratic government.

Despite the existing connection between the post-communist and the present-day political situation in Poland, the analysis illustrated that contemporary protest movements are shaped by a different environment, forcing them to adapt their activities accordingly. Still existing democratic structures enable them to perform within the constitutional framework of the state and in a manner that transcends national borders. Anti-communist opposition activities, in contrast, had to operate within a political environment that impeded open discourse and calls for democratic values. Comparing Solidarity and KOD within their respective societal and political surroundings confirms the principal claim that public protest activities are closely linked to the form of regime change: The direction of the transformation process is reflected in the way collective action is exercised and in the kind of agencies, repertoires and targets used. Public protest can thus be seen as a valuable indicator that gives insight into the kind of political change that a state undergoes. Answering the overall research question, the findings demonstrated that public protest movements accompanying a process of democratization have to operate from outside while they aim to target the internal, political setup. In contrast, public protest that aims to counter the reverse development away from democracy is able to exercise pressure from within the state system and to address a wider community outside national borders. 
These overarching patterns that characterize the relation between public protest and regime change allow to apply the insights gained from the Polish case to other developments in contemporary politics. The situation in Hungary, for instance, resembles the one in Poland as both countries' democratic system is gradually weakened from within, indicating that both states are currently undergoing a regime change that dissolves democratic structures. Comparable to KOD, groups such as the Hungarian youth party "Momentum" attempt to counter the imminent political transformation, determined to overthrow Orbán's authoritarian regime (Varga, 2017). In order to prove the general validity of the findings, it would be interesting to apply the chapter's research design to investigate whether the interaction of public protest and collective action in Hungary is resembling the Polish case.

As citizens' movements seem to mirror the political environment they are operating within, they are an important indicator that can give insight into the political state of a country. It remains to see whether the Polish civil society and other European protest movements such as "Momentum" in Hungary are able to counter the consolidation of illiberal elements that are undermining the democratic systems in those countries. What unites public protest activities all across Europe is their common desire for a stable state based on democratic structures that secure citizens' rights and freedoms. Combining their efforts across the continent could strengthen their calls for democracy beyond borders and increase the pressure on illiberally acting national governments. Anticommunist dissident movements such as Solidarity have proven to be a good example, successfully fighting for a common cause: the establishment of a democratic government. 